\title{
Influence of School Counsellor's Demographic on the Provision of Guidance Services in Senior High Schools in Ghana
}

\author{
Bernard Kissi-Abrokwah, Anontise Isaac Aboyom, Ebenezer Bamfo Aidoo, Grace Mensah and \\ Hansen Akoto-Baako
}

\begin{abstract}
This study investigates how school counsellor's demographics influence the provision of guidance services in senior high schools in Ghana. The study was underpinned by a positivist philosophical viewpoint where a quantitative approach and the descriptive survey was used to assess how school counsellor's demographics influence their provision of guidance services. A self-developed questionnaire was used to collect data from respondents. A total of a hundred and thirtysix (136) respondents was selected on a purposive base. The study found out that there was a significant difference between the age, gender, experience and academic qualification of counsellors have an influence in the provision of guidance services in SHSs in Ghana. The study also revealed that orientation, information and counselling services were adequately performed in SHSs, but consultation and follow-up were the least provided services. The study recommended that the Ministry of Education should ensure that the employment criteria for school counsellors should be based mostly on academic qualification and experience. Finally, the Ministry of Education and Ghana Education Service should organise seminars for school counsellors frequently to have rudimentary knowledge and skills to help them in practice.
\end{abstract}

Keywords - Counsellor demographics, Ghana, guidance services, senior high school, school counsellors.

\section{INTRODUCTION}

Guidance is a programme of services for students based on their needs. Guidance can also be seen a broad professional field with a wide range of activities geared towards assisting students to better understand themselves and to develop an adequate capacity for making wise choices of decision making in life [1]. School guidance are services design to ensure that students develop to their full potential in life [2]. These services are appraisal, consultation, counselling, follow-up, placement, orientation, information, referral, and evaluation. An effective provision of these services most depend on many variables and one of such variables is demographic information of the counsellor or the knowledgeable person providing the services [3].

Researchers like [4]-[6] all have made significant contribution on the provision of guidance services. However, issues of guidance services are not new because [4] conclude

Published on October 27, 2021.

B. Kissi-Abrokwah, C. K. Tedam University of Technology and Applied Sciences, Nvrongo, Ghana.

(corresponding e-mail: bkissiabrokwah @cktutas.edu.gh)

A. I. Aboyom, C. K. Tedam University of Technology and Applied Sciences, Nvrongo, Ghana.

(e-mail: aboyomike @yahoo.com) that guidance programmes and their related activities have been part of professional dialogue since the 1920s. On developing countries like Ghana, Kanya and Nigeria, the concern for checking the provision of guidance services have received much effort by school counsellors which have contributed to students' success and development [4], [5].

However, effective guidance practice also depends on training and practicum received by counsellor-trainees in school. In the same vein, [7] recommends that counsellors' active participation and authorities support to ensure effective provision of guidance services in schools. The researcher also concludes that long-schooling and training is important for the provision of guidance services but much of the effort depend on counsellor's experience to put in place activities to promote guidance services [3]. Reference [8], [9] concluded that the level of education of school counsellors inform their abilities to provide or implement effective guidance services in school. Reference [10] confirm that training of counsellors helps in the provision of healthy school environment where guidance activities can prevail. Reference [11] added that effective provision of guidance services large depend on the appropriate skill and psychological knowledge gain by the counsellor during their practicum.

Reference [12] asserted that counsellors age does not have impact in the delivery of guidance services, but the age serves as a compliment to experience and maturity on how the counsellor should handle situation in schools. Reference [13] assessment on effects of large class size on effective teaching and learning show that hours spent by teachers in school affect their ability to support effective guidance delivery in SHSs. However, [14] agree that planning and assessment of students are more difficult when teachers are supervising more class. Reference [15] suggested that the qualified counsellors with good demographics background, increasing or improving facilitation of guidance services in SHSs. This state of empirical review shows that counsellors demographics have impact on how guidance services are being run in SHSs.

The compulsory institution of guidance centres in the senior high school (SHS) was to help cater for students moral, social physiological and educational difficulties. Upon the compulsory institution of guidance centres in SHSs, report

\footnotetext{
E. B. Aidoo, Accra College of Education, Greater Accra, Ghana. (e-mail: aidooelder72@gmail.com)

G. Mensah, University of Cape Coast, Cape Coast, Ghana

(e-mail: grace.mensah @ucc.edu.gh.com)

H. Akoto-Baako, Jasikan College of Education, Ghana.

(e-mail: akotobaakohansen20@gmail.com)
} 
from [16], [17] indicate that students' indiscipline is on the increase because Kumasi Technical Institute (KTI) students and the police and as a result, 48 students were hospitalised and detained. Again, students in Karaga SHS, Nalerigu SHS and Salaga T. I. Ahmadiya SHS clashed with school authorities and destroyed property including school dormitories, school bus and teachers' bungalows. However, the [18], [19] indicates that, 44,262 and 72,413 students' examination results were withheld pending an investigation into various cases of examination malpractice detected during and after the conduct of the examination.

Due to the cases on examination malpractices and indiscipline by students in SHSs, the researcher intends to investigate how the school counsellor's demographic could help in the provision of guidance services. Studies have shown that counsellors experience, training, academic level and other factors ensure effective provision of guidance services in SHSs [20], [21]. The rationale was to check how counsellor's demographic could help improve the quality of guidance services in SHSs. Hence, the researcher intends to use school counsellors because they are the main implementers when it comes to guidance services and their demographic like experience, academic qualification, training, class size supervise, and number of hours taught per week may or may not have influence on the effectiveness of guidance services practice in SHSs.

The study may provide information on which counsellor's demographic data influence the effectiveness of guidance services practices in SHSs in Ghana. However, the findings may also inform policymakers as to why they should emphasize more on experience, training and academic qualification of counsellors are important component in providing guidance services in SHSs. Lastly, the findings from this study would add up to existing literature in the field of counselling and education.

a) Research question

1. What major guidance services are provided in senior high schools to address students' needs?

b) Research hypothesis

$\mathrm{H}_{\mathrm{A}}$ 1: There is a significant difference between the academic qualification of counsellors and their provision of guidance services in SHSs in Ghana.

$\mathrm{H}_{\mathrm{A}}$ 2: There is a significant difference between years of experience of counsellors and their provision of guidance services in SHSs in Ghana.

$\mathrm{H}_{\mathrm{A}} 3$ : There is a significant difference between class size supervise by counsellors and their provision of guidance services in SHSs in Ghana.

$\mathrm{H}_{\mathrm{A}} 4$ : There is a significant difference between age of counsellors and their provision of guidance services in SHSs in Ghana.

$\mathrm{H}_{\mathrm{A}}$ 5: There is a significant difference between gender of counsellors and their provision of guidance services in SHSs in Ghana.

\section{A. Review on Counsellor Demographics}

Counsellor's training helps them to impact knowledge to student's career trajectories [22]. Again, researchers like [23], [24] acknowledge that professional training is necessary for effective guidance and counselling. Reference [25] also discourse that the quality of guidance services rendered in schools depends on the training of the counsellor. However, [26] confirms that lack of practicum or internship training of school counsellors affect the rudimentary skills and knowledge in providing guidance services in schools. In support, [27] stated that school counsellors lack skills in their school setting because of lack of basic training during schooling. Reference [28] shared similar comments that school counsellors lack routine knowledge in guidance services because they had one-year course training without extensive practicum experience.

A study by [9], shows that counsellors experience influences their daily activities in the provision of guidance services in senior high schools in Kwaebibrem District in the Eastern Region of Ghana. Reference [10] confirmed that counsellors being able to assist students with their personal, social and academic challenges comes at a result their experiences gain and knowledge gain from their field of training. Reference [11], commented that counsellors experiences equip them with appropriate psychological techniques and skill to solve students' challenges.

Reference [29] confirm that counsellors' workload and non-counselling activities like administrative responsibilities appeal on the school counsellors make them ineffective in their provision of guidance services. In addition, [30] found that school counsellors are unable to perform due to clerical and administrative duties which prevent them from providing their guidance services. On the contrary, [31] complain that high learner and teacher ratio negatively affect counsellors in the provision of guidance services. Reference [32] concludes that school counsellors are unable perform their duties due to workload of combining teaching and guidance activities.

Reference [33] suggested that counsellor age have impact in their academic and professional delivery of guidance services in schools. In the same vein, [11] asserted that the age could show experience that individual is in-terms of his/her delivery in guidance activities. On the contrary, [25] posits that gender is a determinant factor in guidance services delivery in schools. He further stated that when a female is the school counsellor, there is a possibility the person may become pregnant and leave for maternity leave which may affect the guidance services in the schools within a time period. But the situation may be different when it comes to male counsellors [25].

\section{B. Review on Guidance Services}

Appraisal service is mostly concerned with providing data that will highlight the individuality of each student. It seeks to establish a distinctive picture of individuals by comparing them to others in terms of quantities of general human characteristics. Appraisal data indicate how one is similar to or different from others [34]. Reference [35] concluded that the appraisal service brings out the uniqueness in an individual. To them, it provides the counsellor with the basis to make a critique on the client based on the facts and data available to arrive at a clearer picture and a better understanding of the client. In addition, [36] state that the concern of school guidance personnel is to help students attain optimum growth and development. For this objective to be achieved, counsellors ought to know better about the student/client in question so that they would be in a better position to help him/her make meaningful decisions and 
choices. Reference [25] concluded in a study that students in SHSs in the Sagnarigu District in the Northern Region were of the opinion that appraisal services were beneficial to them because their academic performance has improved.

Reference [37] states that consultation as an aspect of guidance work together with all agencies that matter in the student life. In support, [38] concluded that maladjusted problems such as absenteeism, lateness and truancy are solved by school counsellors with the help of consultation service. Addition, [39] said that consultation service help school counsellors to interpret test scores for students and parents. Reference [40] concludes in a study that consultation provided in SHSs in the Central Region of Ghana helped minimise truancy, sleeping in class and improved academic performance of students. By its usage in this study, consultation in the SHSs entails the process where school counsellors hold discussions and collaboration with teaching staff, non-teaching staff and parents, among others, to resolve the educational, vocational, and personal problems of students.

The school counselling service is an integral and essential component of the educational process for all students [41]. Reference [42] concludes that students with social-personal, educational/academic, adjustment, and development crisis are solved through effective counselling. However, [43] asserted that counselling service provide the key solutions to student's maladjusted behavior.

Reference [44] said that follow-up service involves activities that are designed to monitor the progress of students who avail themselves to counselling and are now outside school or are still in school. Reference [45] added that followup studies of former students' efficient ways are what educational institutions can use for measuring the effects of school counselling. Reference [46] states that the measurement of guidance service outcomes is very important and is mostly done through follow-up services that past students and beneficiaries of guidance services can be appraised to ascertain the effectiveness or otherwise of the entire guidance programme.

Reference [37] concludes that information service is the guidance service that is responsible for generating, coding, storing, retrieving, and disseminating information to students. The information service is primarily aimed at making available to students' knowledge of opportunities on educational, social, and vocational issues to enable them to make choices and decisions that are authentic and reliable. Reference [34] added that information service helps students acquire relevant knowledge which will help them to gain insight in order to attain their specific purpose. It also helps to enhance their understanding of the world around them.

Reference [37] asserts that day in day out, people find themselves in a new situation. It may be in a school setting, a workplace, or any activity. To adjust favorably to any of these areas, one must go through orientation. Reference [47] added that an orientation service is an organized group of activities through which students are given assistance to adjust to the school environment. It is one of the organized guidance services that are carried out by the school to assist new students to be acquainted with human and material resources in the environment. Thus, it is a formal welcome of new students into an institution.
Reference [34] concluded that placement is concerned with assisting students to enter occupations, taking into consideration their achievement, aptitude, interests, and goals. In effect, it involves helping students to find suitable jobs. Social placement, on the other hand, is planned to help develop the social skills of children. Children are placed in social groups that will foster social interaction and enhance self-acceptance. Placement services as used in this study refers to the process where school counsellors assist and guide students to choose their programmes of study based on their qualification, interest, abilities, and aptitudes. In the same vein [36] state that the primary emphasis of placement services includes creating an understanding of the many problems that confront students' immediate and long-range planning; determining how to do something about them; placement of college-bound students in their classes and subject areas; and employment placement, among others.

Reference [39] asserted that referral service is the activity whereby the school counsellors in consultation with the parents of students seeks special assistance from a person or agency in order to help students resolve their problems. This means that the transferring school counsellor cannot provide the specialized assistance needed by the students. Students sometimes face different challenging situations which need special attention. Even though the school counsellors and his team, by their profession, are supposed to help students resolve their diverse problems, they are not always able to do that. The school counsellors are supposed, to be frank with the student and direct him to other specialists for assistance $[6]$.

\section{Methodology}

The study was based on positivist philosophical assumption concerning how knowledge was gained and acquired. Per the assumption, the researcher align himself with the quantitative approach where descriptive survey design was used to obtain information concerning the current status of the phenomena [48]. The targeted population consisted of all counsellors in SHSs in the regional capitals in Ghana. The total population of SHSs in the sixteen regional capitals were 136 . The researcher purposively selected all the SHSs in the regional capital. Again, the researcher used the purposive sampling technique to select 136 school counsellors because each SHSs have one school counsellor.

The instrument used for data collection was structured questionnaire which was pilot tested in in Sekondi-Takoradi in the Western region in Ghana. Using Cronbach's $\alpha$, the questionnaire yielded an $\alpha$ level of 0.851 for test 1 and 0.831 for test 2. The overall $\alpha$ level for the instrument was 0.841 . Permission was also obtained from the Ministry of Education before approaching the 136 counsellors within the Tamale, Kumasi, and Cape Coast of Ghana. Prior to data collection the researcher discussed ethical consideration with the participants. The ethical consideration discussed were informed consent, anonymity, and confidentiality. The data analysis was done using descriptive and inferential statistics. The statistical package for social sciences (SPSS) was used in sorting, coding, and analysing. The descriptive statistic was on mean and standard deviation while the inferential statistics used were ANOVA and T-test to examine the different 
between groups.

\section{RESULTS}

This section shows the descriptive statistics of the provision of guidance services practiced in Ghana.

The rationale behind Table I was to assess how frequent counsellors practice these guidance services in senior high schools (SHSs). From Table I, orientation service recorded mean and standard deviation score $(\mathrm{M}=7.82, \mathrm{SD}=0.56)$ which represent high response rate. The result found under orientation service section show that "My school provides orientation for students when they come to school" recorded $(\mathrm{M}=3.91, \mathrm{SD}=0.28)$ was the highest response rate. The second statement that respondents identify as the most frequent guidance service was "My school helps students to get acquainted and to cope with the school environment" recorded $(\mathrm{M}=3.91, \mathrm{SD}=0.28)$. Again, the result shows that school has calendar of events for the year was highly practice under information service with a mean and standard deviation score of $(\mathrm{M}=3.80, \mathrm{SD}=0.39)$. However, the last theme reported under information service was "My school provides information about many careers and educational opportunities to students" recorded $(\mathrm{M}=3.73, \mathrm{SD}=0.45)$.

However, the next frequent guidance service used by counsellors was the counselling service. The theme recorded mean and standard deviation score $(\mathrm{M}=3.85, \mathrm{SD}=0.36)$ shows that teacher/counsellor helped students to achieve their personal growth. Respondents highlighted that "School guidance and counselling has helped students to avoid problems" was the second frequent provision used under the counselling. This theme recorded a mean and standard deviation value of $(\mathrm{M}=3.49, \mathrm{SD}=0.50)$. Again, the mean and standard deviation score of $(\mathrm{M}=3.47, \mathrm{SD}=0.50)$ gives an indication school set examination to know the students' performance. However, the second theme under appraisal service shows that students' classroom work exposes them to their career preferences $(\mathrm{M}=3.51, \mathrm{SD}=0.50)$.

The respondents suggested that "Teachers refer students to the counsellor when they have a peculiar problem" recorded $(\mathrm{M}=3.32, \mathrm{SD}=0.47)$ while "Teachers send students to the nurse when they have health problem for solutions" also recorded $(\mathrm{M}=3.30, \mathrm{SD}=0.46)$. The scales found under the referral service all recorded mean scores above (3.00).

However, respondents that they assist students with educational and social adjustment in school which recorded mean and standard deviation value $(\mathrm{M}=2.81, \mathrm{SD}=0.97)$ while the second theme under placement service recorded $(\mathrm{M}=3.21$, $\mathrm{SD}=1.05$ ) representing counsellors assisting students in choosing courses based on their interest in school. The mean and standard deviation value $(\mathrm{M}=2.30, \mathrm{SD}=1.15)$ shows that counsellor consults parents in coping with or modifying students' behaviour in class. Table I shows that "counsellor consults parents to assist students' when they have a problem in class" recorded $(\mathrm{M}=2.13, \mathrm{SD}=0.94)$. Lastly, Table I revealed that "respondents do follow-ups when students come to me with their problems", recorded $(\mathrm{M}=2.13, \mathrm{SD}=1.21)$. On issues of "monitor students' progress whenever they discuss issues concerning their academic challenges" recorded $(\mathrm{M}=2.18, \mathrm{SD}=0.95)$. In conclusion, the assessment from Table I shows that counsellors found in SHSs in Ghana were effectively providing orientation, information, counselling, appraisal, and least guidance services provided were followup and consultation.

TABLE I: DESCRIPTIVE STATISTICS ON PROVISION OF GUIDANCE SERVICES IN SHSS

\begin{tabular}{|c|c|c|c|}
\hline Statement & $\mathrm{N}$ & $\overline{\mathrm{M}}$ & StD \\
\hline \multicolumn{4}{|l|}{ Orientation Service } \\
\hline $\begin{array}{l}\text { My school provides orientation for } \\
\text { students when they come to school. } \\
\text { My school helps student to get }\end{array}$ & 136 & 3.91 & 0.28 \\
\hline $\begin{array}{l}\text { acquainted and to cope with the school } \\
\text { environment. }\end{array}$ & 136 & 3.91 & 0.28 \\
\hline Total of Orientation Service & & 7.82 & 0.56 \\
\hline \multicolumn{4}{|l|}{ Information Service } \\
\hline $\begin{array}{c}\text { My school has calendar of events for } \\
\text { the year. }\end{array}$ & 136 & 3.80 & 0.39 \\
\hline $\begin{array}{l}\text { My school provides information about } \\
\text { many career and educational } \\
\text { opportunities to students. }\end{array}$ & 136 & 3.73 & 0.45 \\
\hline Total of Information Service & & 7.53 & 0.84 \\
\hline \multicolumn{4}{|l|}{ Counselling Service } \\
\hline $\begin{array}{l}\text { Teacher/counsellor helped students to } \\
\text { achieve their personal growth. }\end{array}$ & 136 & 3.85 & 0.36 \\
\hline \multirow{2}{*}{$\begin{array}{c}\text { School guidance and counselling has } \\
\text { helped students to avoid problems. } \\
\text { Total of Counselling Service } \\
\text { Appraisal Service }\end{array}$} & 136 & 3.49 & 0.50 \\
\hline & & 7.34 & 0.86 \\
\hline $\begin{array}{l}\text { School set examination to know the } \\
\text { students' performance. }\end{array}$ & 136 & 3.47 & 0.50 \\
\hline \multirow{2}{*}{$\begin{array}{l}\text { Students' classroom work exposes } \\
\text { them to their career performance. } \\
\text { Total of Appraisal Service }\end{array}$} & 136 & 3.51 & 0.50 \\
\hline & & 6.98 & 1.00 \\
\hline
\end{tabular}
Referral Service

Teachers refer students to the

$\begin{array}{llll}\text { counsellor when they have a peculiar } & 136 & 3.32 & 0.47\end{array}$ problem.

Teachers send students to the nurse when they have health problem for solutions. Total of Referral Service

\begin{tabular}{rrr}
136 & 3.30 & 0.46 \\
& 6.62 & 0.93 \\
\hline
\end{tabular}

Placement Service

I assist students with educational and social adjustment in school.

I assist students in choosing courses based on their interest in

\begin{tabular}{lll}
136 & 2.81 & 0.97 \\
136 & 3.21 & 1.05 \\
& 6.02 & 2.02 \\
\hline
\end{tabular}

Total of Placement Service

Consultation Service

Teacher/counsellor consults parents in coping with or modifying students' behaviour in class. $136 \quad 2.30 \quad 1.15$

Teacher/counsellor consults parents to assist students' when they have a problem in class.

Total of Consultation Service

\begin{tabular}{lll}
136 & 2.13 & 0.94 \\
& 4.43 & 2.09 \\
\hline
\end{tabular}

Follow-up Service

I do follow-ups when students come to me with their problems.

$136 \quad 2.13 \quad 1.21$

I monitor students' progress whenever they discuss issues

concerning their academic challenges.

Total of Follow-up Service

Source: Field data (2020).

$4.31 \quad 2.16$

\section{A. Hypothesis One}

The analysis was done to check the differences that exist between academic qualification and provision of guidance services. The descriptive statistics shows counsellors with master's degree were effective with the provision of guidance services. Table II shows a mean and standard deviation score of $97(\mathrm{M}=52.47, \mathrm{SD}=3.83, \mathrm{SR}=.39)$. however, counsellors with other certificate and diploma certificate recorded second and third from Table II while those with degree score last in 
term of the mean and standard deviation. From Table II the F-ratio (18.206) was significant $(\mathrm{p}=0.000)$ was less than the alpha level 0.05 . The researcher accepts the alternate hypothesis stated as "There is a significant difference between the academic qualification of counsellors and their provision of guidance services in SHSs in Ghana". Although the analysis from ANOVA recorded sig value $(\mathrm{p}=0.000)$ but the researcher could not specifically tell where the differences came from unless multiple comparisons (Post Hoc Tests) was conducted. The Post-Hoc test shows there was significant differences between academic qualification and provision of guidance services. From Table II there was difference between academic qualification (Diploma and Masters), (Bachelor and Masters) recorded a sig value of $0.01 *$ (2tailed) show that there was a statistically significant difference between academic qualification and provision of guidance services in SHSs. Again, Table II yielded a significant difference $(p=0.003)$ representing academic qualification (Other and Masters). Form the finding in Table II, the researcher accepts the alternate hypothesis stated as "There is a significant difference between the academic qualification of counsellors and their provision of guidance services in SHSs in Ghana" with small Eta effect size of 0.29 using [49], format.

\section{B. Hypothesis Two}

The analysis was done to check the differences that exist between working experience and counsellors' provision of guidance services in SHSs in Ghana. From Table III counsellors with 16 years and above recorded $55(\mathrm{M}=53.09$, $\mathrm{SD}=4.04, \mathrm{n}=55$ ). However, counsellor's experience less than 5 and 11-15 scored second and third with the mean score of $(\mathrm{M}=50.92, \mathrm{SD}=2.84, \mathrm{n}=13)$ and $(\mathrm{M}=50.77, \mathrm{SD}=3.49, \mathrm{n}=22)$ which falls with the magnitude of 0.79 and 0.74 . Again, the summary of ANOVA from Table III recorded a mean and standard score of $(\mathrm{M}=48.80, \mathrm{SD}=3.79, \mathrm{n}=46)$ which falls on 0.56 standard error. From Table III the F-ratio (10.820) was significant $(\mathrm{p}=0.000)$ was less than the alpha level 0.05 . The researcher will reject null hypothesis and accepts the alternate hypothesis stated as "There is a significant difference between years of experience of counsellors and their provision of guidance services in SHSs in Ghana". The analysis of Post-Hoc test shows that difference existed between counsellors who have experience between (6-10 and 16-above).

TABLE II: SUMMARY OF ANOVA (ACADEMIC QUALIFICATION AND PROVISION GUIDANCE SERVICE)

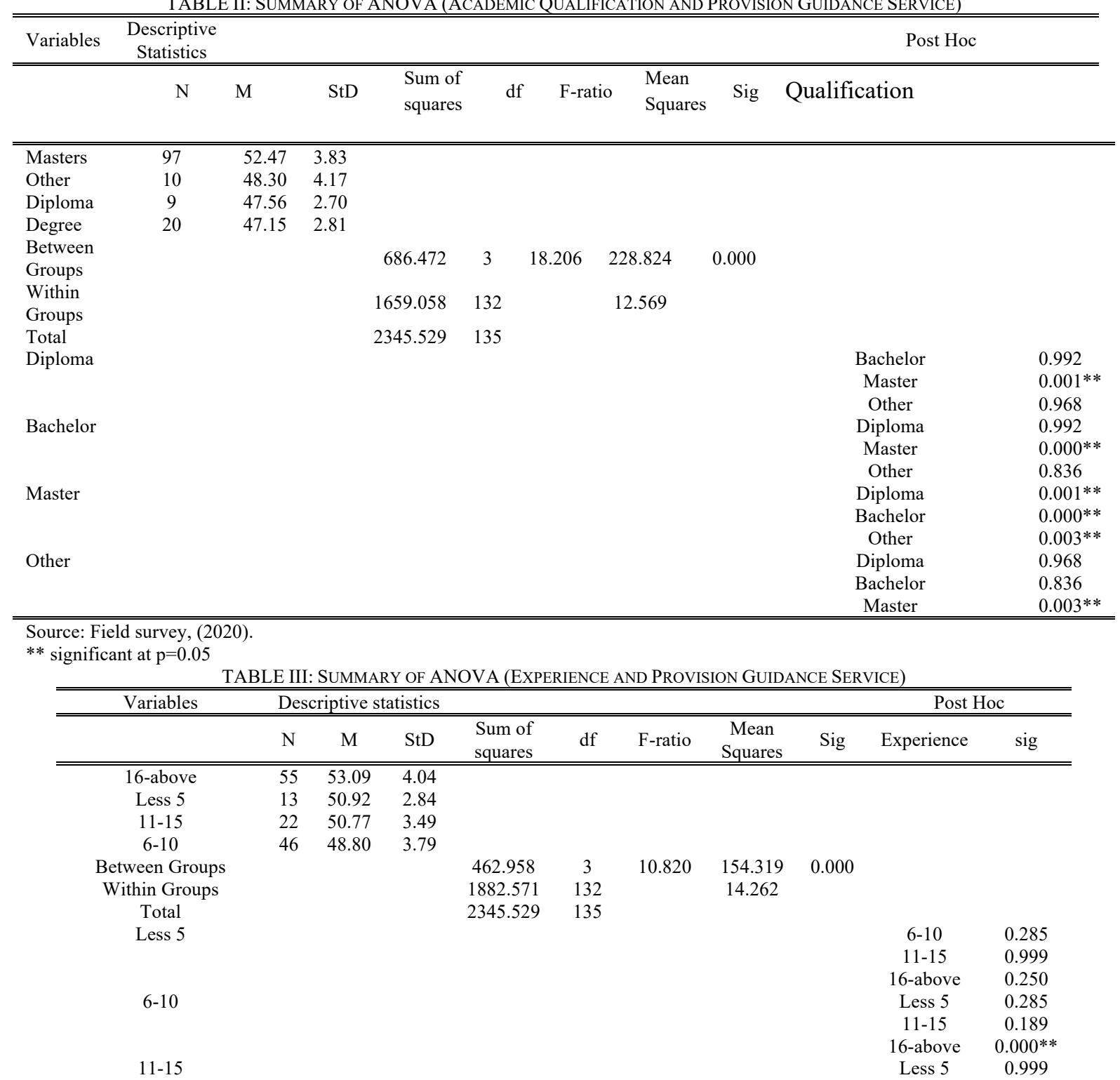




\begin{tabular}{|c|c|c|}
\hline \multirow{5}{*}{ 16-above } & $6-10$ & 0.189 \\
\hline & 16-above & 0.076 \\
\hline & Less 5 & 0.250 \\
\hline & $6-10$ & $0.000 * *$ \\
\hline & $11-15$ & 0.076 \\
\hline
\end{tabular}

Source: Field survey, (2020).

** significant at $\mathrm{p}=0.05$.

\section{Hypothesis Three}

Table IV report the summary of ANOVA between class size and provision guidance service. The descriptive statistics shows counsellors supervising class size between 51-60, 61above and 41-50 face challenges in the provision of guidance service. To confirms this, F-ratio (9.132) was significant $(p=0.000)$ was less than the alpha level 0.05 . The researcher accepts the alternate hypothesis stated as "There is a significant difference between class size supervise by counsellors and their provision of guidance services in SHSs in Ghana". Although the analysis shows a significant value $(p=0.000)$, but the researcher could not tell where the differences came from unless multiple comparisons (Post Hoc Tests) was conducted. The Post-Hoc test shows that difference existed between class size (41-50 and 51-60) and (41-50 and 61-above). In support, [32] said that school counsellors are unable perform their duties due to workload of combining teaching with guidance activities.

\section{Hypothesis Four}

The analysis from Table $\mathrm{V}$ shows that counsellors age groups between 41-50, 51-60 and 31-40 were providing effective guidance services in SHSs. The significant value of 0.000 was less than alpha level 0.05 . It was concluded that "There is a significant difference between age of counsellors and their provision of guidance services in SHSs in Ghana". The post Hoc test show that differences exist between counsellors age groups (41-50 and 31-40) and (41-50 and 5160).

\section{E. Hypothesis Five}

An independent-sample T-test was conducted to compare the gender and provision of guidance services. Table VI shows significant level 0.003 which was smaller than $p=0.05$, the evident shows that the data has violated the assumption of equal variance. The researcher used the equal variance not assumed figures were used to interpret the findings. Table VI shows that there was significant difference in scores for female $(\mathrm{M}=52.14, \mathrm{SD}=4.15)$ and male $(\mathrm{M}=48.35, \mathrm{SD}=2.79 ; \mathrm{t}$ $(-5.238)=9.314, p=0.05$, two-tailed). From the results found in Table VI, the alternate hypothesis stated as "There is a significant difference between gender of counsellors and their provision of guidance services in SHSs in Ghana" provided was accepted.

TABLE IV: SumMARY OF ANOVA (CLASS Size AND PROVISION GUIDANCE SERVICE)

\begin{tabular}{|c|c|c|c|c|c|c|c|c|c|c|}
\hline \multirow[t]{2}{*}{ Variables } & \multicolumn{8}{|c|}{ Descriptive statistics } & \multicolumn{2}{|c|}{ Post Hoc } \\
\hline & $\mathrm{N}$ & $\mathrm{M}$ & StD & Sum of squares & $\mathrm{df}$ & F-ratio & Mean Squares & Sig & Class Size & sig \\
\hline $251-60$ & 43 & 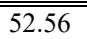 & 5.00 & & & & & & & \\
\hline $30-40$ & 7 & 51.57 & 2.57 & & & & & & & \\
\hline 61-above & 61 & 51.36 & 3.36 & & & & & & & \\
\hline $41-50$ & 25 & 47.60 & 2.71 & & & & & & & \\
\hline Between Groups & & & & 403.145 & 3 & 9.312 & 134.382 & 0.000 & & \\
\hline Within Groups & & & & 1942.385 & 132 & & 14.715 & & & \\
\hline Total & & & & 2345.529 & 135 & & & & & \\
\hline \multirow[t]{3}{*}{$30-40$} & & & & & & & & & $41-50$ & 0.078 \\
\hline & & & & & & & & & $51-60$ & 0.922 \\
\hline & & & & & & & & & 61-above & 0.999 \\
\hline \multirow[t]{3}{*}{$41-50$} & & & & & & & & & $30-40$ & 0.078 \\
\hline & & & & & & & & & $51-60$ & $0.000 * *$ \\
\hline & & & & & & & & & 61-above & $0.000 * *$ \\
\hline \multirow[t]{3}{*}{$51-60$} & & & & & & & & & $30-40$ & 0.922 \\
\hline & & & & & & & & & $41-50$ & $0.000 * *$ \\
\hline & & & & & & & & & 61-above & 0.401 \\
\hline \multirow[t]{3}{*}{ 61-above } & & & & & & & & & $30-40$ & 0.999 \\
\hline & & & & & & & & & $41-50$ & $0.000 * *$ \\
\hline & & & & & & & & & $51-60$ & 0.401 \\
\hline
\end{tabular}

Source: Field survey, (2020).

** significant at $\mathrm{p}=0.05$.

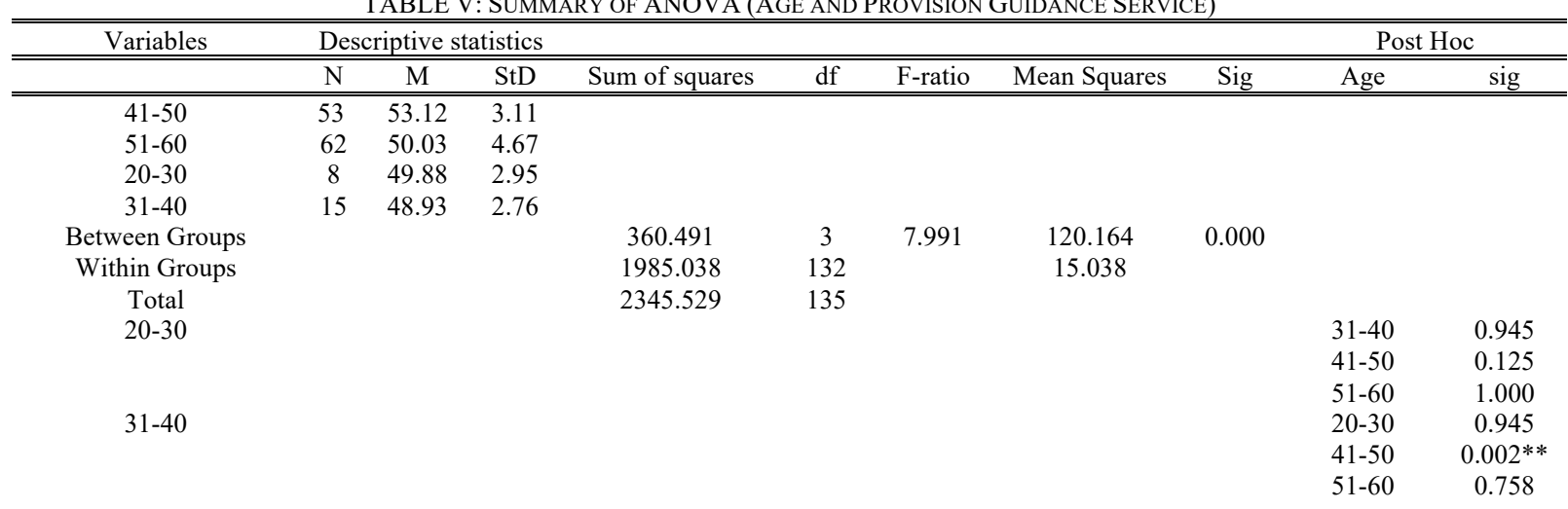




\begin{tabular}{|c|c|c|}
\hline \multirow[t]{2}{*}{$41-50$} & $20-30$ & 0.129 \\
\hline & $31-40$ & $0.002 * *$ \\
\hline \multirow{4}{*}{$51-60$} & $51-60$ & $0.000^{* *}$ \\
\hline & $20-30$ & 1.000 \\
\hline & $31-40$ & 0.758 \\
\hline & $41-50$ & $0.000 * *$ \\
\hline
\end{tabular}

Source: Field survey, (2020).

** significant at $\mathrm{p}=0.05$.

TABLE VI: INDEPENDENT SAMPLE T-TEST FOR GENDER AND PROVISION OF GUIDANCE SERVICES

\begin{tabular}{cccccccc}
\hline \hline Variable & $\mathrm{N}$ & $\mathrm{M}$ & $\mathrm{StD}$ & F-ratio & t-value & Conformation $\begin{array}{c}\text { Conclusion } \\
\text { of sig-level }\end{array}$ \\
\hline \hline Female & 97 & 52.14 & 4.15 & 9.314 & -5.238 & 0.003 & $\begin{array}{c}\mathrm{H}_{\mathrm{A}} \\
\text { Accepted }\end{array}$ \\
Male & 39 & 48.35 & 2.79 & & & & \\
\hline \hline $\begin{array}{l}\text { Source: Field survey, (2020). } \\
\text { ** significant at } \mathrm{p}=0.05 .\end{array}$ & & & & & & & \\
\hline
\end{tabular}

\section{DISCUSSION}

It was revealed that academic qualification of counsellors has significant impact in their provision of guidance services in SHSs in Ghana. The researcher believes that when counsellor acquire the rudimentary skills and techniques used in training and modifying students' behavior, they would be able to assist students well. Again, the knowledge gain from long schooling could also help with their guidance activities in school. In support, [22] concluded that the training of counsellors has impact in their students' trajectories. In the same vein, [23], [24] asserted that effective training of counsellors reflects in their performance in school. On the contrary [26] confirms that lack of practicum or internship training affect counsellor's knowledge in applying basic rudimentary skills and techniques in schools.

Concerning counsellors experience it was revealed that the longer field training or practicum gain on the field have positive impact on the counsellor's effectiveness. Again, the practical skills and techniques about the core conditions in counselling are gain from an experience person whom the counsellor would understudying for a long time. In support, [10] confirmed that counsellor's ability to provide assistance comes from the experiences gain from their field of training during practicums. Reference [11] added that experience gain by a counsellor on the field of training help in their psychological techniques and skill to solve students' challenges.

It was reviewing that the class size supervised by most school counsellors have impact on their effectiveness in providing guidance services. The researcher believes that when counsellors are given less workload in class, they would be able to have time to provide the necessary guidance services to help students with their personal-social, career and emotional problems. When counsellors supervise more students in class, they would be exhorted due to long hours of teaching and heavy workload may affect their abilities to provision of guidance services. In support, [32] concludes that school counsellors are unable perform their duties due to workload of combining teaching and guidance activities. On the contrary, [29] confirm that counsellors' workload and non-counselling activities like administrative responsibilities affect their inability to provide effective guidance services. Reference [30] found that school counsellors are unable to perform due to clerical and administrative duties which prevent them from providing their guidance services.

The result from the study show that counsellor's age has impact in their provision of guidance services. With reference from Table $\mathrm{V}$, the age grouping 20-30 was not significant to other age groupings but the age groupings 41-50 and 50-60 were significant to other groups. This means that students who are mature and have acquired long schooling and have gone through the necessary practicum are able to provide guidance service than those who are not mature and have just completed school. Reference [33] suggested that counsellor age have impact in their academic and professional delivery of guidance services in schools. In the same vein, [11] asserted that the age could show experience that individual is in-terms of his/her delivery in guidance activities.

The study showed that counsellor's gender has a significant impact in their provision of gender services in school. Table VI shows that female counsellors were performing well with the mean and standard deviation score $(\mathrm{M}=52.14, \mathrm{SD}=4.15)$ as against their male counterpart who recorded $(\mathrm{M}=48.35, \mathrm{SD}=2.79)$. On the contrary, [25] posits that gender is a determinant factor in guidance services delivery in schools. He further stated that when a female is the school counsellor, there is a possibility the person may become pregnant and leave for maternity leave which may affect the guidance services in the schools within a time period. But the situation may be different when it comes to male counsellors [25].

\section{CONCLUSION}

- The study revealed that school counsellors' years of experience, academic qualification, age, gender, and class size have impact in the provision of guidance services in SHSs in Ghana.

- The study concluded that at the reopening of schools, counsellors provide orientation and information services adequately but fail to consult parent about students' needs and also do not follow-up to check how students responding to the therapeutic treatment after counselling.

- The study concludes that counsellor demographics enhance the provision of effective guidance services assist students to harmonize their abilities, interests and values and thereby develop their full potential. 


\section{RECOMMENDATIONS}

1. The Ministry of Education should ensure that the employment criteria for school counsellors should be based most on academic qualification and experience.

2. The Ministry of Education and Ghana Education Service should organize seminars for school counsellors frequently to have rudimentary knowledge and skills to help them in practice.

3. An appropriate plan or guideline under which the school counsellor must operate should be well established in the schools. The guideline should be carved out of the national guidelines but must be tailored to meet the specific needs of the members of each school community. This guideline should also be made aware to counsellors in executing their duties so that they will not only concentrate on orientation, counselling and information but should practices consultation and follow-up services which were the least provided in SHSs in Ghana.

\section{REFERENCES}

[1] UNESCO, Terms of reference. The first international conference on guidance, counselling and youth development in Africa. Kenya, Nairobi, 2002.

[2] G. Awabil and E. Namane, Guidance needs of senior secondary school students in the Bulsa and Kassena Nankana District of the Upper East Region. Journal of Counselling, Education and Psychology, 1(1), 86$101,2013$.

[3] B. Kissi-Abrokwah, Evaluation of guidance services in senior high schools in Ghana. A thesis submitted to College of Education in University of Cape Coast, 2019.

[4] J. Mapfumo and E. Nkoma, The state of guidance and counselling programme in high schools in Manicaland, Zimbabwe. International Journal of Scientific Research in Education. 6(2), 100-116, 2013.

[5] W. McGannon, J. Carey and C. Dimmitt, The current status of school counselling outcome research (Research Monograph No. 2). Amherst, MA: Centre for School Counselling Outcome Research, University of Massachusetts, School of Education, 2005.

[6] E. Nyarko-Sampson, Teacher trainees' appraisal of guidance and counselling programmes in colleges of education in Eastern and Greater Accra Zones. Nigeria Journal of Guidance and Counselling, 15(1),95-111, 2010.

[7] K. W. Ofosu-Dwamena, Perceptions of school authorities toward guidance and counselling in Ghana. Unpublished Master's Thesis, Department of Psychology and Education, University of Education, Winneba, 2012.

[8] H. Atta-Frimpong, Assessing the effectiveness of guidance and counselling in St. Joseph's College of Education-Bechem. Unpublished Master Thesis submitted to the Department of Educational Foundations, University of Cape Coast, 2013.

[9] D. A. Mintah, Assessment of the Effectiveness of Guidance and Counselling Services in Second Cycle Schools in The Kwaebibrem District in the Eastern Region of Ghana. Unpublished Master Thesis submitted to the Department of Educational Foundations, University of Cape of Coast, 2012.

[10] R. Bor, J. Ebner-Landy, S. Gill and C. Brace, Counselling in schools. London: Sage Publications, 2002.

[11] N. P. Njeri, The Influence of Guidance and Counselling Programme on Academic Performance of Selected Public Secondary School Students: A Case of Bahati Division, Nakuru District. Unpublished Master of Education Degree in Guidance and Counselling of Egerton University, 2007.

[12] J. B. Tita-Nghamun, “An Appraisal of Effective Provision of Guidance and Counseling Services in Cameroon State Universities; Trends and Challenges," International Journal of Humanities Social Sciences and Education 3(9): 75-90, 2016.

[13] D. Yelkpieri, M. Namale, K. Esia-Donkoh and E. Ofosu-Dwamena, "Effects of Large Class Size on Effective Teaching and Learning at the Winneba Campus of the UEW (University of Education, Winneba), Ghana," US-China Education Review 3, 319-332, 2012.
[14] J. Benbow, A. Mizrachi, D. Oliver and L. Said-Moshiro, Large class sizes in the developing world: What do we know and what can we do? Educational Quality Improvement Programme (EQUIP 1) and USAID, 2007.

[15] Joy FM, Police hit hard at KTI students; 14 hospitalised, 48 arrested. www.myjoyonline.com/news/2017 retrieval on 09/06/2017, 2017.

[16] Savannah News, Rioting senior high school students in Northern Region dismissed .http://savannahnewsblogspotcom. blogspot.com/2015/08/rioting-shs-students-in-northern-region.html, 2015.

[17] West African Examiners Council (WAEC) Chief Examiners Report, Assessment of Students Examination Results.https://www.waecgh.org/ EXAMS/Chief Examiners Report. aspx, 2016.

[18] West African Examiners Council (WAEC) Chief Examiners Report, Assessment of Students Examination Results. https://www.waecgh.org/ EXAMS/Chief ExaminersReport.aspx, 2020.

[19] F. F. Afande, "Effect of guidance and counselling on pupils in public primary schools in Makadara Division of Nairobi Province," Research on Humanities and Social Sciences 5(5): 23-36, 2015.

[20] M. Ahyia, Examination of students 'views on guidance and counselling services in Ghana. Unpublished Masters Thesis submitted to the Department of Educational Foundations, University of Cape Coast, 2010.

[21] G. W. Wambu and A. F. Teresa, "School guidance and counselling in Kenya: Historical development, current status, and future prospects," Journal of Education and Practice 6(11): 92-102, 2015

[22] J. Charema, "School counsellors' perceptions of guidance and counselling in secondary school in Botswana," The Nigerian Journal of Guidance and Counselling 13(1): 158-170, 2008.

[23] E. O. Egbochuku, Guidance and counselling: A comprehensive text. Benin City: University of Benin Press, 2008.

[24] A. A. Asamari, The provision of guidance services in Colleges of Education in Northern Ghana. Unpublished Doctorate Thesis, submitted to the Department of Psychology and Education, University of Education, Winneba, 2015.

[25] M. Asare-Owusu, The need for guidance and counselling programme in Schools. Unpublished Master's Thesis submitted to the Department of Psychology and Education, University of Education, Winneba, 2016.

[26] W. R. Ansah, Challenge facing the school guidance and counselling programme in Ghana. Unpublished Master's Thesis, submitted to the Department of Psychology and Education, University of Education, Winneba, 2009.

[27] K. A. Ofori, Perceptions of school authorities toward guidance and counselling in Ghana. Unpublished Master's Thesis, Department of Psychology and Education, University of Education, Winneba, 2012.

[28] MOEST, Kenya Educational Sector Support Service 2005- 2010: Delivering Quality Education and Training to all Kenyans. Nairobi: MOEST, 2005.

[29] P. O. Paisley, "Maintaining and Enhancing the Developmental Focus in School Counselling Programmes," Professional School Counselling 4 (4): 271-277, 2007.

[30] J. Reynolds and J. Cheek, "The habits of highly effective texas school counsellors," TCA-Journal 30(1): 86-98, 2002.

[31] C. J. Samoei, Challenges faced by teachers and head teachers in maintaining. Unpublished Doctorate Thesis, School of Education. University of Nairobi, 2009.

[32] D. A. Mintal, Assessment of the Effectiveness of Guidance and Counselling Services in Second Cycle Schools in The Kwaebibrem District in the Eastern Region of Ghana. Unpublished Master Thesis submitted to the Department of Educational Foundations, University of Cape of Coast, 2012

[33] A. I. Taylor and D. K. Buku, Basics in guidance and counselling. Ghana, Accra: Yamens Press Ltd, 2006.

[34] E. A. Akinade, B. O. Sokan and N. Osarenren, An introduction to guidance and counselling: A basic text for colleges and universities, Ibadan, Nigeria: Caltop Publication Ltd, 2005.

[35] G. Kankam and A. O. Onivehu, Principles and practice of guidance and counselling. Accra: K'NAB Ltd, 2000.

[36] M. K. Numale, Guidance and counselling in education. Cape Coast: Yaci Publications, 2007.

[37] A. I., Taylor \& Buku, D. K Buku, Basics in guidance and counselling. Ghana, Accra: Yamens Press Ltd, 2010.

[38] N. K. Pecku, Introduction to guidance for training colleges, Accra, Ghana: University Press, 1991.

[39] M. Sackey, An evaluation of guidance services in secondary school students in the Central Region. Unpublished Master Thesis submitted to the Department of Psychology and Education, University of Education, Winneba, 2007. 
[40] S. M. Schlossberg, The effects of a counsellor-led guidance intervention on students' behaviours and attitudes. Professional School Counselling, 4, 156-182, 1984.

[41] D. C. Mawusi, The support of counselling services to the indiscipline in public junior high schools. The case of South Tong District in the Volta Region. Unpublished Masters Thesis submitted to the Department of Psychology and Education, University of Education, Winneba, 2013.

[42] D. Nicholson and H. Ayers, Individual counselling theory and practice: A reference guide. New York: David Fulton, 1995.

[43] R. Nelson-Jones, Practical counselling and helping skills. London: Cassell, Wellington, 1997.

[44] J. A. Omotosho, Fellow-up studies of former students as an efficient measure of the effects of schooling, Research on schooling in Nigeria: Introductory reading. Ondo, centre for research on schooling, 1995.

[45] O. Makinde, Fundamentals of guidance and counselling. London: Macmillan Ltd, 1990.

[46] W. Stephenson, Testing school children. New York: Longmans, Green, 1999.

[47] J. W. Creswell and J. D. Creswell, Research design: qualitative, quantitative, and mixed methods approaches. Sage publications, 2018.

[48] J. Cohen, Statistical Power Analysis for the Behavioral Sciences. New York, NY: Routledge Academic, 1988.

[49] W. R. Ansah, Challenge facing the school guidance and counselling programme in Ghana. Unpublished Master's Thesis, submitted to the Department of Psychology and Education, University of Education, Winneba, 2009.

[50] R. Chiresche, "Guidance and counselling programme development in Countries," International Journal for the Advancement of Counselling 12(3): 191-201, 2006.

[51] E. Nyarko-Sampson, "Students' Perception of Guidance and Counselling Services offered in Colleges of Education in the Volta Region," Nigeria Journal of Guidance and Counselling 21(1): 1-13, 2016.

[52] S. M. Schlossberg, "The effects of a counsellor-led guidance intervention on students' behaviours and attitudes," Professional School Counselling 4, 156-182, 2001. 